\title{
Front Matter: Volume 9650
}

, "Front Matter: Volume 9650," Proc. SPIE 9650, Technologies for Optical Countermeasures XII; and High-Power Lasers 2015: Technology and Systems, 965001 (29 October 2015); doi: 10.1117/12.2217605

SPIE. Event: SPIE Security + Defence, 2015, Toulouse, France 


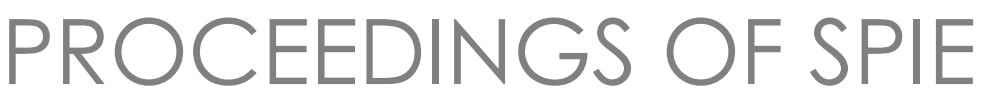

\title{
Technologies for Optical Countermeasures XII; and High-Power Lasers 2015: Technology and Systems
}

\author{
Harro Ackermann \\ Willy L. Bohn \\ David H. Titterton \\ Robert J. Grasso \\ Mark A. Richardson \\ Editors
}

21, 23-24 September 2015

Toulouse, France

Sponsored by

SPIE

Cooperating Organisations

European Optical Society

Optitec (France)

Route des Lasers (France)

Published by

SPIE 
The papers in this volume were part of the technical conference cited on the cover and title page. Papers were selected and subject to review by the editors and conference program committee. Some conference presentations may not be available for publication. Additional papers and presentation recordings may be available online in the SPIE Digital Library at SPIEDigitallibrary.org.

The papers reflect the work and thoughts of the authors and are published herein as submitted. The publisher is not responsible for the validity of the information or for any outcomes resulting from reliance thereon.

Please use the following format to cite material from these proceedings:

Author(s), "Title of Paper," in Technologies for Optical Countermeasures XIl; and High-Power Lasers 2015: Technology and Systems, edited by Harro Ackermann, Willy L. Bohn, David H. Titterton, Robert J. Grasso, Mark A. Richardson, Proceedings of SPIE Vol. 9650 (SPIE, Bellingham, WA, 2015) Six-digit Article CID Number.

ISSN: 0277-786X

ISSN: 1996-756X (electronic)

ISBN: 9781628418606

Published by

SPIE

P.O. Box 10, Bellingham, Washington 98227-0010 USA

Telephone +1 3606763290 (Pacific Time) · Fax +1 3606471445

SPIE.org

Copyright (C) 2015, Society of Photo-Optical Instrumentation Engineers.

Copying of material in this book for internal or personal use, or for the internal or personal use of specific clients, beyond the fair use provisions granted by the U.S. Copyright Law is authorized by SPIE subject to payment of copying fees. The Transactional Reporting Service base fee for this volume is $\$ 18.00$ per article (or portion thereof), which should be paid directly to the Copyright Clearance Center (CCC), 222 Rosewood Drive, Danvers, MA 01923. Payment may also be made electronically through CCC Online at copyright.com. Other copying for republication, resale, advertising or promotion, or any form of systematic or multiple reproduction of any material in this book is prohibited except with permission in writing from the publisher. The CCC fee code is $0277-786 \mathrm{X} / 15 / \$ 18.00$.

Printed in the United States of America.

Publication of record for individual papers is online in the SPIE Digital Library.

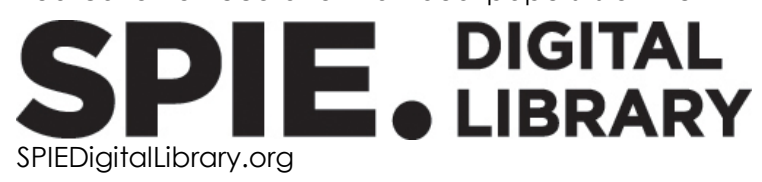

Paper Numbering: Proceedings of SPIE follow an e-First publication model, with papers published first online and then in print. Papers are published as they are submitted and meet publication criteria. A unique citation identifier (CID) number is assigned to each article at the time of the first publication. Utilization of CIDs allows articles to be fully citable as soon as they are published online, and connects the same identifier to all online, print, and electronic versions of the publication. SPIE uses a six-digit CID article numbering system in which:

- The first four digits correspond to the SPIE volume number.

- The last two digits indicate publication order within the volume using a Base 36 numbering system employing both numerals and letters. These two-number sets start with 00, 01, 02, 03, 04, $05,06,07,08,09,0 A, 0 B \ldots$. 0Z, followed by 10-1Z, 20-2Z, etc.

The CID Number appears on each page of the manuscript. The complete citation is used on the first page, and an abbreviated version on subsequent pages. 


\title{
Contents
}

\author{
v Authors \\ vii Conference Committee \\ ix Introduction to Part B: Technologies for Optical Countermea sures
}

\section{Part A High-Power Lasers 2015: Technology and Systems}

\section{LASERS AND LASER ARC HITECTURES FOR POWER SCAUNG}

965002 Recent advances in E³+:YAG solid-state heat-capacity technology (Invited Paper) [9650-1]

965003 Considerations of a ship defense with a pulsed COIL [9650-2]

ADVANCES IN RBER LASERS

965007 High-power near-infrared supercontinuum source generated in an ytterbium-doped fiber amplifier [9650-7]

NEW SINGLE REQUENCY/ NARROW BAND SOUD STATE LASERS

965008 High-average-power narrow-line-width sum frequency generation 589 nm laser [9650-8]

\section{SIMULATIONS AND EXPERIMENTS IN DIODE-PUMPED ALKAU LASERS}

9650 OA Supersonic diode pumped alkali lasers: Computational fluid dynamics modeling (Invited Paper) [9650-10]

$9650 \mathrm{OB}$ Modeling of pulsed KDPALtaking into account the spatial variation of the pump and laser intensities in the transverse direction [9650-11]

9650 OC CFD assisted simulation of temperature distribution and laser power in pulsed and CW pumped static gas DPALs [9650-12]

9650 OD Low pressure cesium and potassium Diode Pumped Alkali Lasers: pros and cons (Invited Paper) [9650-13]

9650 OE 3D CFD modeling of subsonic and transonic flowing-gas DPALs with different pumping geometries (Best Student Paper) [9650-14] 


\section{Part B Technologies for Optical Countermeasures}

\section{AIRCRAFTPROTECTION}

9650 0H Potential of preemptive DIRCM systems (Invited Paper) [9650-23]

9650 ol Quantific ation of helic opter rotor downwash effects on electro-optical defensive aids suites [9650-24]

ATMOSPHERIC AND EXTERNALPLATFORM ETEC TS UPON LASER PROPAGATION

$9650 \mathrm{OL}$ Expenimental and numerical analysis of atmospheric propagation of high energy laser [9650-27]

9650 OM Helicopter engine exhaust rotor downwash effects on laser beams [9650-28]

PULSE MODULATION AND SIGNATURE ERECTS

9650 ON IRCM spectral signature measurements instrumentation featuring enhanced radiometric accuracy [9650-30]

POSTER SESSION

965000 Different pulse pattem generation by frequency detuning in pulse modulated actively mode-locked ytterbium doped fiber laser [9650-29] 


\section{Authors}

Numbers in the index correspond to the last two digits of the six-digit citation identifier (CID) article numbering system used in Proceedings of SPIE. The first four digits reflect the volume number. Base 36 numbering is employed for the last two digits and indicates the order of articles within the volume. Numbers start with 00, 01, 02, 03, 04, 05, 06, 07, 08, 09, 0A, 0B...0Z, followed by 10-1Z, 20-2Z, etc.

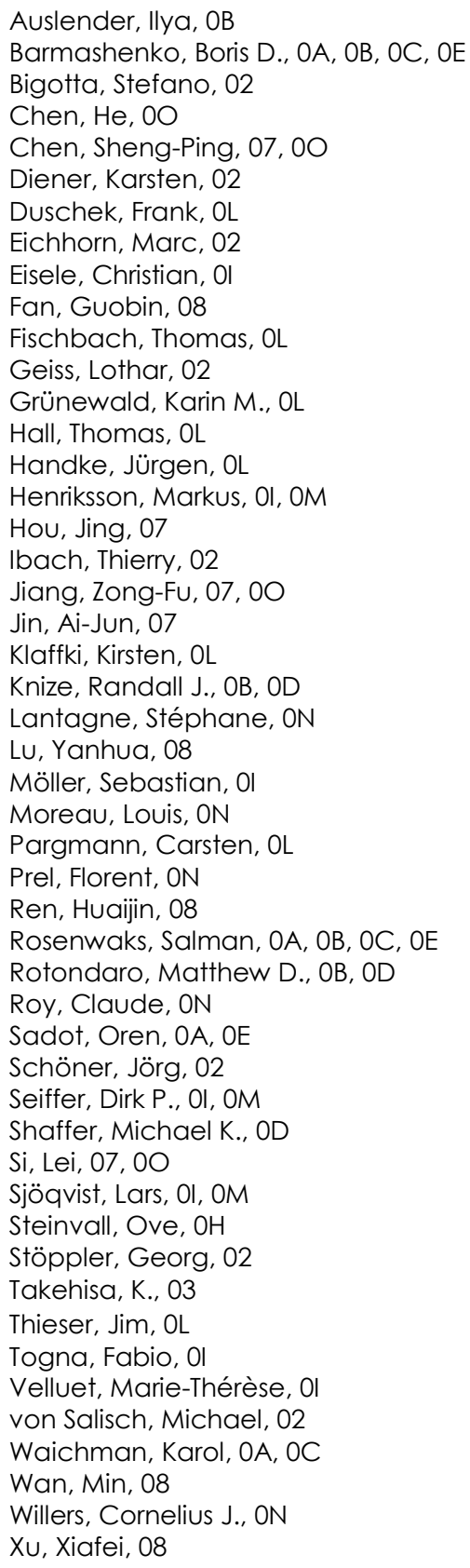

\author{
Yacoby, Eyal, OA, OE \\ Zhang, Bin, 07, 00 \\ Zhang, Lei, 08 \\ Zhang, Wei, 08 \\ Zhdanov, Boris V., OB, OD
}


Proc. of SPIE Vol. $9650965001-6$

Downloaded From: https://www.spiedigitallibrary.org/conference-proceedings-of-spie on 26 Apr 2023 Terms of Use: https://www.spiedigitallibrary.org/terms-of-use 


\title{
Conference Committee
}

\author{
Symposium Cha ir
}

David H. Ttterton, UK Defense Academy (United King dom)

Symposium Co-chair

Reinhard Ebert, Fraunhofer-Institut für Optronik, Systemtec hnik und Bildauswertung (Germany)

\section{Part A: $\quad$ High-Power Lasers 2015: Tec hnology and Systems}

Conference Chairs

Hamo Ackemann, High Energy La ser J oint Tec hnology Office (United States)

Willy L Bohn, BohnLaser Consult (Gemany)

Session Chairs

$1 \quad$ Lasers and Laser Architec tures for Power Scaling

Willy L Bohn, BohnLaser Consult (Gemany)

2 Advances in Fiber Lasers

Willy L Bohn, BohnLaser Consult (Gemany)

3 New Single Frequency/Na row Band Solid State Lasers

Willy L Bohn, BohnLa ser Consult (Gemany)

$4 \quad$ Simulations and Experiments in Diode-Pumped Alkali Lasers

Salman Rosenwaks, Ben-Gunion University of the Negev (Israel)

\section{Part B: Technologies for Optical Countermeasures}

Conference Chairs

David H. Ttterton, UK Defence Aca demy (United Kingdom)

RobertJ. Grasso, EOIR Technologies (United States)

Conference Programme Committee

Brian Butters, Meon Technology Limited (United Kingdom) 
Marc Eichhom, Institut Franco-Allemand de Recherches de Sa intLouis (France)

lan F. Eder, SELEX Ga lileo Ltd. (United Kingdom)

David B. James, Cranfield University (United Kingdom)

Helena Jelinkova, Czech Technical University in Prague

(Czech Republic)

Gerald C. Manke II, Naval Surface Warfa re Center Crane Division (United States)

Espen Lippert, Norwegia n Defence Resea rch Esta blishment (Norway)

Eric D. Park, Q-Peak, Inc. (United States)

Ric H. M. A. Schleijpen, TNO Defence, Sec unity a nd Safety (Netherlands)

Dirk Peter Seiffer, Fra unhofer-Institut für Optronik, Systemtec hnik und Bild a uswertung (Gemany)

Ove Steinvall, FOI-Swedish Defence Research Agency (Sweden)

Hans-DieterTholl, Diehl BGTDefence G mbH \& Co. KG (Gemany)

Maria S. Willers, Denel Dynamics (South Afric a)

Comelius J. Willers, Council for Sc ientific and Industrial Research (South Africa)

Session Chairs

5 Keynote Session

Robert J. Grasso, EOIR Technologies (United States)

David H. Ttterton, UK Defence Aca demy (United Kingdom)

$6 \quad$ Airc raft Protection

Stuart Duncan, SELEX G a lileo Ltd. (United Kingdom)

$7 \quad$ La sers and Sourc es for C ountemeasures

David H. Ttterton, UK Defence Aca demy (United Kingdom)

8 Atmospheric and Extemal Platform Effects upon Laser Propagation

Mark A. Richardson, Cranfield University (United Kingdom)

Hans-Dieter Tholl, Diehl BG TDefence G mbH \& Company KG

(Gemany)

9 Pulse Modulation and Signature Effects

Ove Steinvall, FOI-Swedish Defence Research Agency (Sweden)

Leon Smith, Cranfield University (United King dom) 


\title{
Introduction to Part B: Technologies for Optical Countermeasures
}

This was the twelfth time we have held this conference, conducted over two days, and offered a range of papers pertinent to Electro-Optical and Infrared Countermeasures. As in the past, we also held our panel disc ussion debating the topic of "IRCM - Back to the Future". This disc ussion is very popular and caused some very interesting discussion, especially when the topic of "where do we move from here and how do we get there given technology and cost constra ints" was raised.

This year's conference had five sessions, which focused upon Aircraft Protection, Laser Technology, and Atmospheric, Platform, and Signature Effects. There were two exceptional papers in the keynote session, which addressed "Semiconductor Lasers for DIRCM" and "Advancement in High Power MIR Sources." In the following sessions there were invited presentations covering Pre-emptive DIRCM System Arc hitec tures, Helic opter Rotor Downwash Effects, and High Energy Laser Propagation Effects. Of particular interest was our session on, "Atmospheric and Extemal Platform Effects upon Laser Propagation." Here we had two excellent papers dealing with "Experimental and Numerical Analysis of Propagation of High-Energy Beams," and "Helicopter Engine Exhaust Rotor Downwash Effects on Laser Beams." Both of these papers deal with what we get at the end of the propagation chain once rotor downwash effects, atmospheric propagation effects, and absomtion and scattering take their toll on our otherwise perfect beam emanating from our system.

We wish to thank all of the presenters for delivering an outstanding conference; moreover, we also thank the Programme Committee for their continued support and willingness to chair the various sessions, which is also appreciated by SPIE. The chaimen encouraged the audience to consider topics for disc ussion at next year'sconference and symposium, which will be held in Edinburgh, Scotland.

\author{
David H. Titterton \\ RobertJ. Grasso
}

Mark A. Richardson 
Proc. of SPIE Vol. $9650965001-10$

Downloaded From: https://www.spiedigitallibrary.org/conference-proceedings-of-spie on 26 Apr 2023 Terms of Use: https://www.spiedigitallibrary.org/terms-of-use 